Financial reports of Van Buren County, Iowa. First to twentyeighth, 1902-1929, issued 1903-1930.

Stump, Mary J. Correspondence with reference to the Stump family of Selma, Van Buren County, Iowa.

Harlan, E. R. Mauscript notes copied from the original record book of the Board of County Commissioners of Van Buren County.

Hodges, Cornelia C. County Superintendent of school of Van Buren County, Keosauqua. Correspondence, particularly with reference to the place-names Flat Rock, Franklin, Girard, Home Prairie, Mount Zion (in Des Moines Township), Prairie Queen, Stone, and Webster Ridge.

Pittman, E. F. Correspondence, particularly with reference to the place-names Eim, Mount Zion, West Home Prairie, etc., as well as correction of personal names.

Heminger, A. L. Correspondence, giving pertinent comments on various place-names as indicated in the text.

\title{
RIVALRY OF BURLINGTON AND DAVENPORT
}

The Sun stands up manfully for Davenport, and does not seem to relish our remarks about its insignificance. Abandoning the hope of having the legislature convene at that point the next session, it consoles itself with the reflection that ultimately the seat of government must be near them. This we grant, and believe; but it furnishes the executive with no good reason for assembling the people's representatives at that place now when about three-fourths of the population lies below it. The editor talks about Burlington "falling into decay." This is all fudge. The population of Burlington at this day is equal to the whole of Scott County.-Iozea Territorial Gazette, Burlington, I. T., August 25, 1838. (In the Newspaper Division of the Historical, Memorial and Art Department of Iowa.) 
Copyright of Annals of Iowa is the property of State of Iowa, by \& through the State Historical Society of Iowa and its content may not be copied or emailed to multiple sites or posted to a listserv without the copyright holder's express written permission. However, users may print, download, or email articles for individual use. 